\title{
Sistem Modulator dan Demodulator BPSK dengan Costas Loop
}

\author{
Budihardja Murtianta \\ Program Studi Teknik Elektro, \\ Fakultas Teknik Elektronika dan Komputer, \\ Universitas Kristen Satya Wacana, Salatiga \\ budihardja.murtianta@staff.uksw.edu
}

\section{Ringkasan}

Pada tulisan ini akan dibahas suatu sistem transmisi data berbasis BPSK (Binary Phase Shift Keying) menggunakan Costas Loop pada demodulatornya. Pada prinsipnya Costas Loop adalah bentuk khusus dari PLL yang difungsikan untuk melakukan demodulasi sinyalsinyal yang termodulasi secara supressed-carrier. Costas Loop menggunakan umpan balik negatif untuk melakukan carrier recovery, kemudian sinyal pembawa yang dihasilkan digunakan untuk melakukan demodulasi sinyal BPSK-nya. Sistem ini terdiri dari modulator dan demodulator BPSK yang menggunakan format Non Return Zero Bipolar. Pada sistem modulator BPSK akan menghasilkan isyarat $\mathrm{A}_{\mathrm{c}} \cos \left(\omega_{\mathrm{c}} \mathrm{t}\right)$ untuk menyatakan "high" dan - $\mathrm{A}_{\mathrm{c}}$ cos $\omega_{c}$ untuk menyatakan "low" sedang pada sistem demodulator BPSK akan menghasilkan aras "high" untuk isyarat yang sefasa dan menghasilkan aras "low" untuk isyarat berbeda fasa $180^{\circ}$.

Kata kunci: Binary Phase Shift Keying, Costas Loop, carrier recovery

\section{Pendahuluan}

Modulasi digital yang sering digunakan adalah Amplitudo Shift Keying (ASK), Frequency Shift Keying (FSK) dan Phase Shift Keying (PSK).

1. Amplitudo Shift Keying (ASK)

ASK adalah jenis modulasi digital yang paling sederhana. Jenis modulasi ini menggunakan amplitudo berbeda untuk menyatakan bit 1 dan 0. Modulasi ASK yang menggunakan kondisi hidup (on) dan kondisi mati (off) untuk menyatakan data 1 dan 0 disebut OOK (On Off Keying). Sinyal yang termodulasi OOK dapat digambarkan seperti pada Gambar 1 di bawah ini.

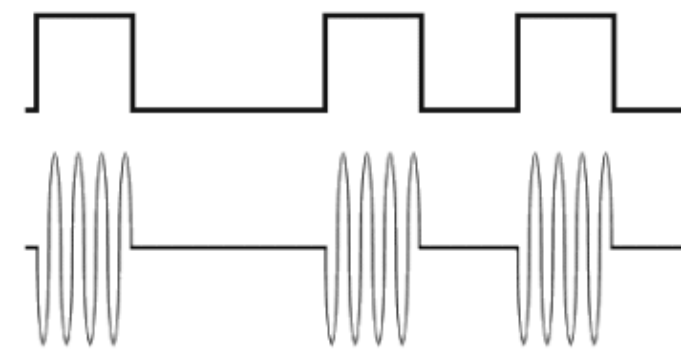

Gambar 1. Sinyal OOK. 
2. Frequency Shift Keying (FSK)

Modulasi FSK menggunakan frekuensi yang berbeda untuk menyatakan data 1 dan 0, seperti dapat dilihat pada Gambar 2 di bawah ini.
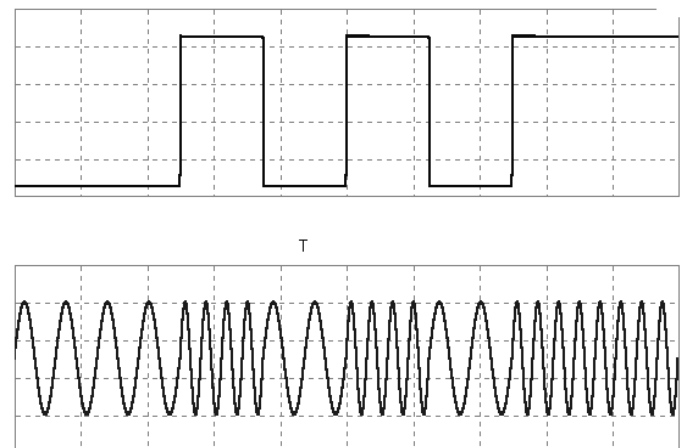

Gambar 2. Sinyal FSK.

3. Phase Shift Keying (PSK)

Jenis modulasi yang terakhir adalah modulasi PSK. Modulasi ini menggunakan fasa yang berbeda untuk menyatakan data 1 dan 0 , biasanya digunakan beda fasa $0^{0}$ dan $180^{\circ}$ seperti pada Gambar 3 di bawah ini.
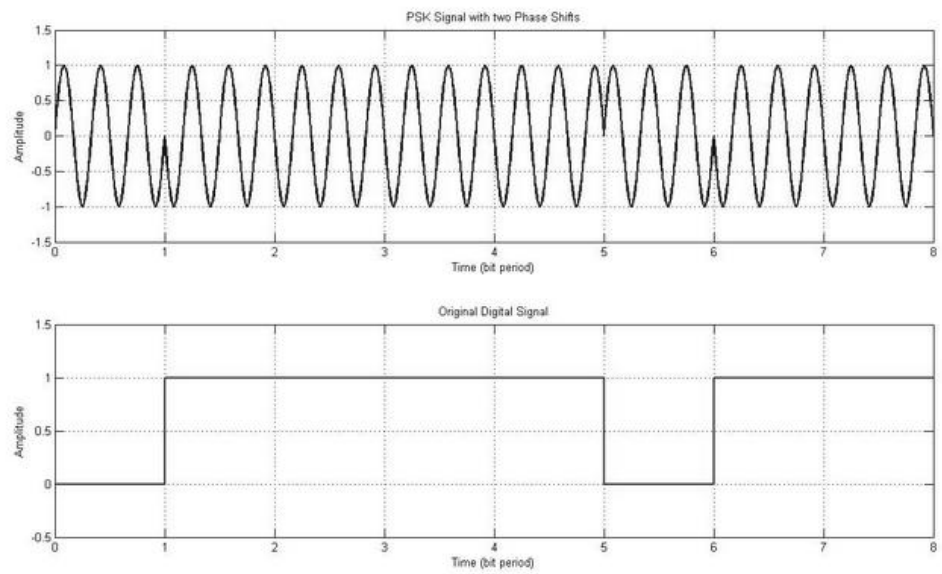

Gambar 3. Sinyal PSK.

Lebar pita paling lebar adalah modulasi FSK, sedangkan kemungkinan kesalahan yang terjadi yang paling kecil adalah modulasi PSK. Pada tulisan ini akan dibahas modulasi dan demodulasi sinyal BPSK (Binary Phase Shift Keying). BPSK adalah jenis modulasi $P S K$ untuk sinyal informasi yang hanya berupa bit 1 dan 0 saja.

\section{Modulasi dan Demodulasi BPSK}

Modulasi BPSK menyatakan bit 1 dan 0 dengan menggunakan fasa yang berbeda. Biasanya digunakan beda fasa $180^{\circ}$ antara bit 1 dengan bit 0 . Secara sederhana modulator BPSK dapat direalisasikan dengan menggunakan sebuah modulator setimbang yang akan mengalikan data biner dengan format bipolar (NRZ Bipolar) dengan sinyal pembawanya, seperti dapat dilihat pada Gambar 4 di bawah ini. 


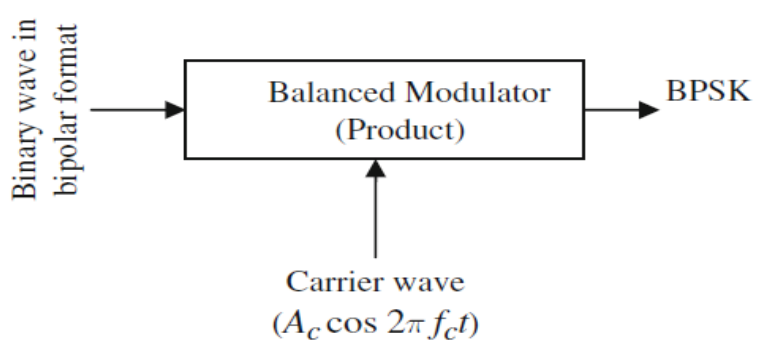

Gambar 4. Bagan Kotak Modulator BPSK Sederhana.

Sinyal BPSK dapat dinyatakan dengan persamaan berikut:

$$
s(t)=\left\{\begin{array}{cc}
A_{c} \cos \left(\omega_{c} t\right) & \text {, saat logika } 1 \\
A_{c} \cos \left(\omega_{c} t+\pi\right)=-A_{c} \cos \left(\omega_{c} t\right) & \text {, saat logika 0 }
\end{array}\right.
$$

Jika dinyatakan dengan data biner format bipolar, maka Persamaan (1) dapat dinyatakan dengan Persamaan (2) berikut ini.

$$
s(t)=m(t) A_{c} \cos \left(\omega_{c} t\right)
$$

Dengan $m(t)$ adalah sinyal data biner dinyatakan dengan persamaan :

$$
m(t)= \begin{cases}+1 & \text {, saat logika } 1 \\ -1 & \text {, saat logika } 0\end{cases}
$$

Pada prakteknya, modulator BPSK sering direalisasikan dengan bagan kotak pada Gambar 5 sebagai berikut.

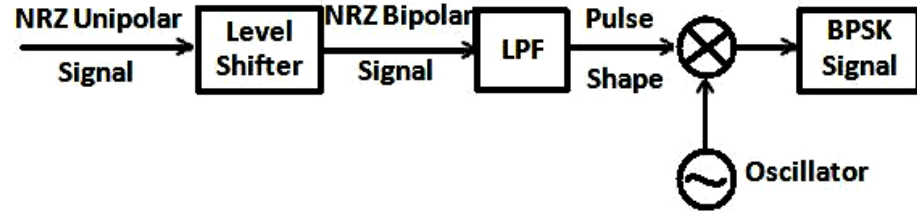

Gambar 5. Bagan Kotak Modulator BPSK.

Proses pembentukan sinyal BPSK dapat dijelaskan seperti pada Gambar 6 berikut ini.

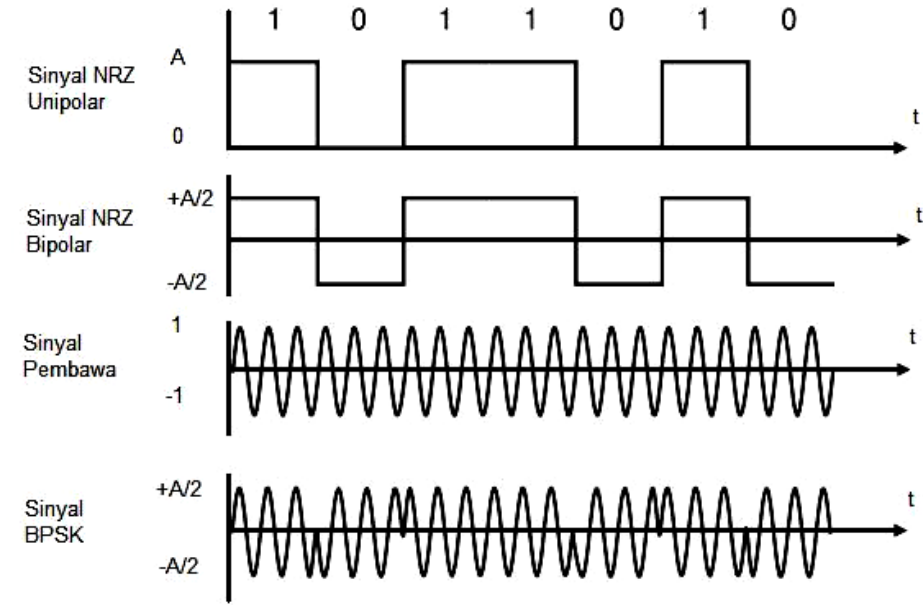

Gambar 6. Proses Pembentukan Sinyal BPSK. 
Keluaran dari sumber data digital biasanya masih berupa sinyal NRZ Unipolar. Sinyal NRZ Unipolar adalah sinyal digital yang menyatakan logika ' 1 ' dengan level tegangan tertentu dan logika ' 0 ' dengan level tegangan 0 Volt. Sedangkan sinyal NRZ Bipolar menyatakan logika ' 1 ' dengan level tegangan positif tertentu dan logika ' 0 ' dengan level tegangan negatif tertentu. Pada proses modulasi sinyal BPSK, sinyal NRZ Unipolar akan diubah menjadi sinyal NRZ Bipolar oleh suatu untai Level Shifter. Keluaran dari Level Shifter akan dikalikan dengan sinyal pembawa yang dihasilkan oleh osilator, hasil perkalian ini akan menghasilkan sinyal BPSK. Pada perancangan suatu modulator BPSK sering ditambahkan tapis pelewat rendah, tapis ini digunakan untuk membatasi lebar pita dari sinyal BPSK yang dihasilkan agar lebar pitanya lebih kecil. Proses demodulasi dari sinyal BPSK harus dilakukan secara koheren [1]. Demodulasi koheren adalah proses demodulasi yang membutuhkan informasi fasa dan frekuensi dari sinyal pembawanya secara tepat [2]. Proses demodulasi sinyal BPSK dapat dilihat pada pada Gambar 7 berikut ini.

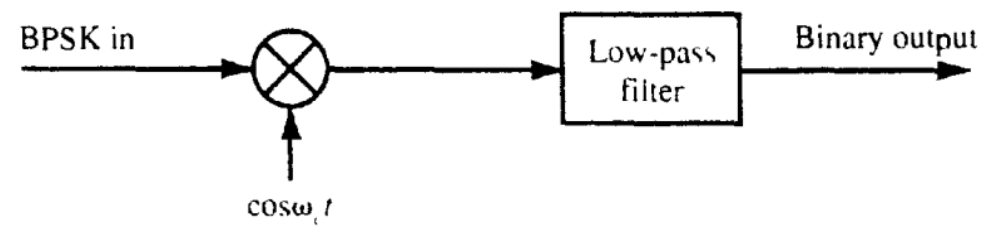

Gambar 7. Demodulasi sinyal BPSK.

Jika sinyal pembawa yang dihasilkan oleh osilator di bagian demodulator dinyatakan dengan Persamaan (4) di bawah ini.

$$
c(t)=\cos \left(\omega_{c} t\right)
$$

Maka keluaran dari pengali akan seperti pada Persamaan (5)

$$
\text { out pengali }=\frac{1}{2} m(t)\left(1+\cos \left(2 \omega_{c} t\right)\right)
$$

Keluaran dari pengali ini akan dilewatkan ke suatu tapis pelewat rendah sehingga akan menghilangkan komponen frekuensi tinggi

$$
\begin{gathered}
2 \omega_{c} \text { out }=\operatorname{LPF}\left(\frac{1}{2} m(t)\left(1+\cos \left(2 \omega_{c} t\right)\right)\right) \\
\text { out }=\frac{1}{2} m(t)
\end{gathered}
$$

Dapat dilihat dari Persamaan (6) di atas, bahwa dengan menapis keluaran pengali dan menghilangkan komponen frekuensi tingginya dapat dihasilkan data biner $m(t)$ yang diinginkan. Salah satu masalah yang muncul pada demodulasi koheren adalah bagaimana mendapatkan informasi tentang frekuensi dan fasa asli sinyal pembawa berdasarkan sinyal pembawa yang telah termodulasi fasanya [3], proses ini sering disebut carrier recovery.

\section{Phase Locked Loop}

PLL adalah suatu osilator yang frekuensi keluarannya akan terkunci (locked) pada suatu komponen frekuensi masukannya, dan proses ini dilakukan dengan menggunakan umpan balik negatif [4]. PLL sering diaplikasikan dalam dunia telekomunikasi, contoh 
aplikasinya adalah untuk carrier recovery, untuk clock recovery dan digunakan untuk demodulasi sinyal FM dan PM. Bagan kotak PLL dapat dilihat pada Gambar 8 yang tersusun dari tiga komponen utama, yaitu :

1. Detektor Fasa

2. Loop Filter

3. Voltage Controled Oscillator (VCO)

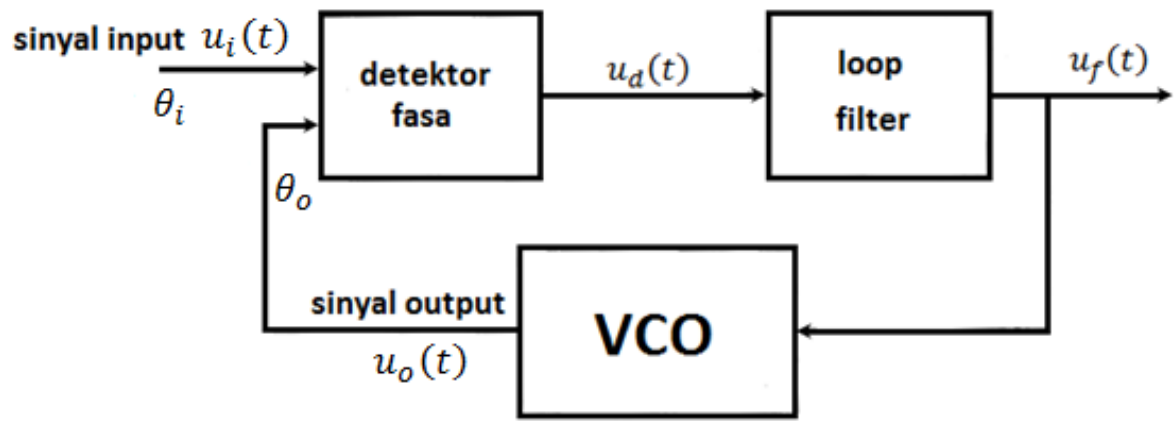

Gambar 8. Bagan Kotak PLL.

\subsection{Detektor Fasa}

Detektor fasa digunakan untuk mendeteksi beda fasa antara kedua masukannya dan akan menghasilkan tegangan keluaran yang sebanding dengan beda fasa kedua sinyal masukannya. Karakteristik dari detektor fasa dapat dinyatakan dengan persamaan:

$$
u_{d}(t)=K_{d}\left(\theta_{i}(t)-\theta_{o}(t)\right)=K_{d} \theta_{e}(t)
$$

Dengan melakukan transformasi Laplace, maka akan didapatkan karakteristik detektor fasa dalam ranah $s$, yang dinyatakan dengan persamaan :

$$
u_{d}(t)=K_{d} \theta_{e}(t) \stackrel{\text { Laplace }}{\longleftrightarrow} U_{d}(t)=K_{d} \theta_{e}(s)
$$

Dalam ranah s (Laplace), detektor fasa dapat dimodelkan seperti pada Gambar 9a.

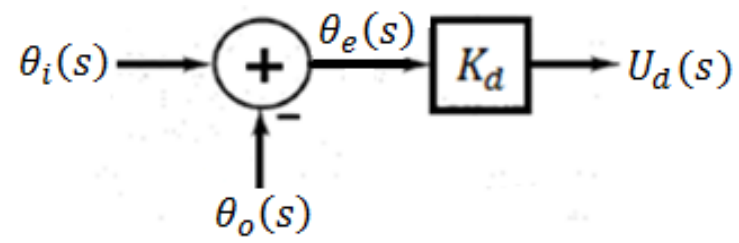

Gambar 9a. Permodelan Linier Detektor Fasa dalam Ranah s.

Salah satu cara merealisasikan detektor fasa adalah dengan menggunakan untai pengali seperti pada Gambar $9 \mathrm{~b}$ berikut.

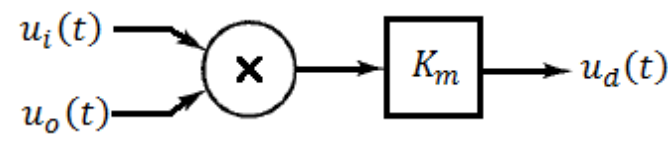

Gambar 9b. Bagan Kotak Pengali.

Dengan $u_{i}(t)$ dan $u_{0}(t)$ adalah kedua masukan pengali, $u_{d}(t)$ adalah keluaran pengali dan $K_{\mathrm{m}}$ adalah bati dari pengali. Persamaan tegangan keluaran untuk pengali dapat dituliskan sebagai berikut. 


$$
u_{d}(t)=K_{m} u_{i}(t) u_{0}(t)
$$

Jika masukan ke pengali adalah :

$$
\begin{gathered}
u_{i}(t)=V_{i} \sin \left(\omega_{i} t\right) \\
u_{o}(t)=V_{o} \cos \left(\omega_{i} t-\theta_{\theta}\right)
\end{gathered}
$$

maka keluaran dari pengali dapat dicari dengan

$$
u_{d}(t)=K_{m}\left(V_{i} \sin \left(\omega_{i} t\right)\right)\left(V_{0} \cos \left(\omega_{i} t-\theta_{\theta}\right)\right)
$$

Dengan menggunakan persamaan trigonometri dasar akan didapatkan :

$$
u_{d}(t)=\frac{1}{2} K_{m} V_{i} V_{o} \sin \left(\theta_{e}\right)+\frac{1}{2} K_{m} V_{i} V_{o} \sin \left(2 \omega_{i} t-\theta_{e}\right)
$$

Bagian frekuensi tinggi dari Persamaan (11) akan diabaikan, karena bagian ini nantinya akan dihilangkan oleh bagian Loop Filter, dan tidak berpengaruh ke sistem. Sehingga persamaan keluaran detektor fasa dapat ditulis menjadi :

$$
u_{d}(t)=\frac{1}{2} K_{m} V_{i} V_{0} \sin \left(\theta_{\theta}\right)
$$

dimana $\Theta_{\mathrm{e}}=\Theta_{\mathrm{i}}-\Theta_{\mathrm{o}}$

\section{2. $\quad \mathrm{VCO}$}

VCO adalah osilator yang menghasilkan sinyal keluaran dengan frekuensi yang sebanding dengan tegangan masukannya. Persamaan karakteristik dari VCO adalah :

$$
\omega_{\text {out }}(t)=\omega_{0}+\Delta \omega_{\text {out }}(t)=\omega_{0}+K_{\text {o }} u_{f}(t)
$$

Besarnya fasa keluaran $V C O \theta_{\text {out }}$ didefinisikan dengan integral dari variasi frekuensi $\Delta \omega_{\text {out }}(t)$, sehingga dapat dituliskan :

$$
\theta_{\text {out }}(t)=\int \Delta \omega_{\text {out }}(t) d t=\int K_{\text {o }} u_{f}(t) d t
$$

Dengan melakukan transformasi Laplace dari persamaan diatas, didapatkan bentuk liniernya :

$$
\theta_{\text {out }}(t)=\int K_{\text {o }} u_{f}(t) d t \stackrel{\text { Laplace }}{\longleftrightarrow} \theta_{\text {out }}(s)=K_{o} \frac{U_{f}(s)}{s}
$$

Berdasarkan Persamaan 11, suatu VCO dapat digambarkan dalam model linier seperti pada Gambar 10.

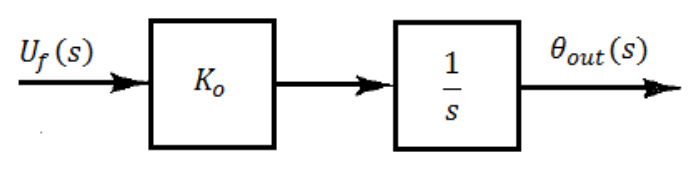

Gambar 10. Model Linier VCO.

\subsection{Loop Filter}

Bagian terakhir dari PLL adalah Loop Filter. Bagian ini berupa suatu tapis pelewat rendah $(L P F)$ yang digunakan untuk menghilangkan komponen frekuensi tinggi keluaran dari detektor fasa dan menghilangkan derau. Dengan menggabungkan permodelan linier dari detektor fasa, VCO dan Loop Filter, maka dalam ranah $s$ (Laplace) suatu PLL dapat dimodelkan seperti pada Gambar 11. 


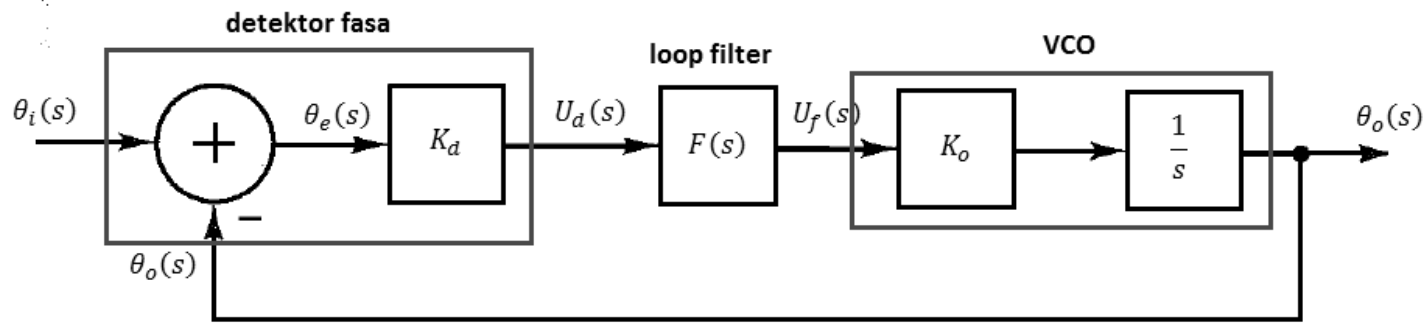

Gambar 11. Permodelan Linier PLL dalam ranah Laplace.

\section{Costas Loop}

Costas Loop dikembangkan oleh John P. Costas pada tahun 1956 untuk melakukan demodulasi sinyal AM Double Sideband Supressed Carrier[3]. Dalam perkembangan selanjutnya, Costas Loop digunakan untuk melakukan demodulasi sinyal-sinyal yang termodulasi secara supressed-carrier dan bagan kotaknya dapat dilihat pada Gambar 12 berikut.

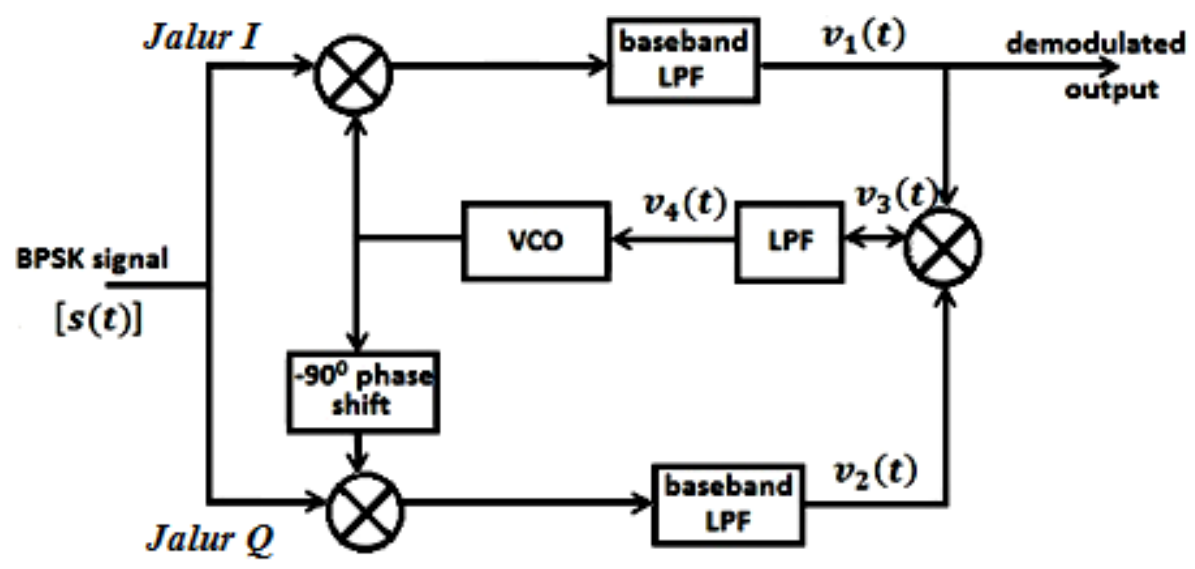

Gambar 12. Bagan Kotak Costas Loop

Pengali di jalur $I$ dan $Q$ digunakan untuk mengetahui beda fasa antara isyarat BPSK $s(t)$ dengan sinyal keluaran $V C O$ (jalur $I$ ) dan sinyal $V C O$ yang digeser fasanya $-90^{\circ}$ (jalur $Q)$. Keluaran dari pengali akan menghasilkan penjumlahan sinyal frekuensi rendah yang memiliki informasi beda fasa dan frekuensi tinggi yang berasal dari penjumlahan fasa dua isyarat sinus tersebut.

Sinyal keluaran pengali di jalur $I$ dan $Q$ akan dilewatkan ke tapis pelewat rendah $(L P F)$, untuk menghilangkan sinyal frekuensi tingginya, karena yang dibutuhkan hanyalah sinyal frekuensi rendah yang memiliki informasi selisih fasa. Keluaran dari jalur $I$ dan $Q$ akan dikalikan oleh suatu pengali ketiga, pengali ini sering disebut bagian phasa doubler.

Keluaran dari pengali ketiga akan dilewatkan ke suatu tapis pelewat bawah ketiga, tapis ini berguna untuk menghilangkan sinyal-sinyal frekuensi tinggi yang masih diloloskan oleh tapis-tapis sebelumnya dan menghilangkan derau. Keluaran dari tapis ketiga ini yang akan mengatur frekuensi keluaran dari VCO.

Costas Loop akan mencapai kondisi terkunci, saat frekuensi dan fasa dari sinyal keluaran VCO sama dengan frekuensi dan fasa dari sinyal pembawa, pada kondisi ini keluaran pada jalur $I$ akan maksimal dan jalur $Q$ akan minimal (mendekati 0). Saat 
kondisi terkunci inilah keluaran pada jalur I adalah data bipolar NRZ hasil demodulasi. Costas Loop adalah sistem yang menggunakan umpan balik negatif, sehingga dapat dimodelkan secara linier pada ranah Laplace seperti sistem umpan balik negatif pada umumnya. Bentuk linier dari suatu sistem dengan umpan balik negatif dapat dilihat pada Gambar 13 berikut.

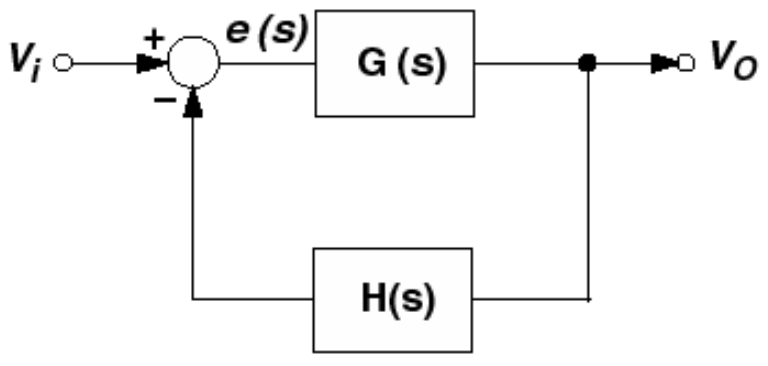

Gambar 13. Bentuk Linier Suatu Sistem Umpan Balik Negatif.

Fungsi pindah loop tertutup dari sistem tersebut adalah :

$$
\frac{V_{o}(s)}{V_{i}(s)}=\frac{G(s)}{1+G(s) H(s)}
$$

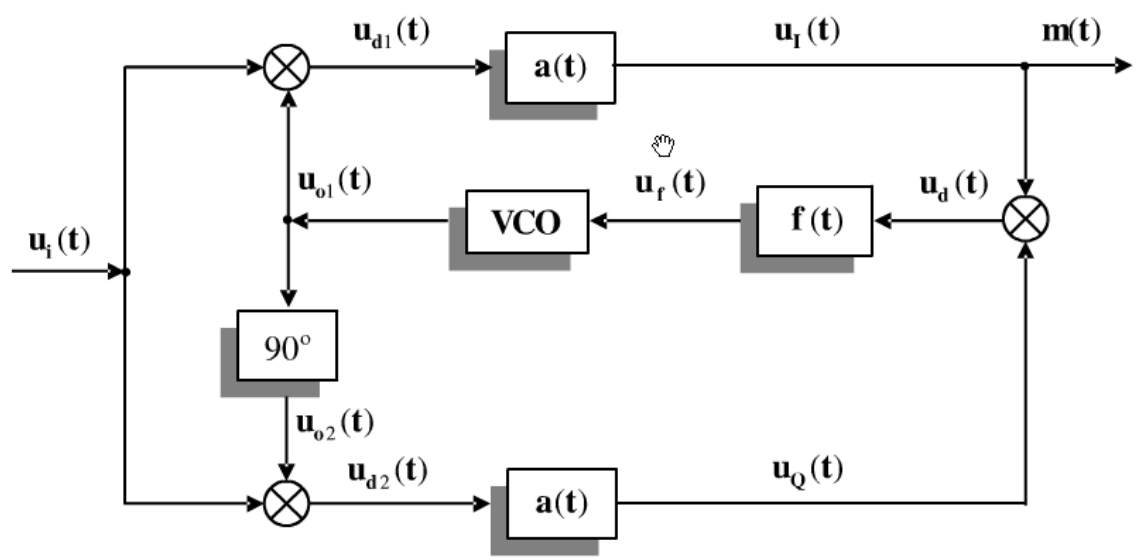

Gambar 14. Diagram Blok Costas Loop secara lengkap.

Gambar 14 adalah diagram blok Costas Loop yang digambarkan lebih lengkap dengan sinyal-sinyal masukan dan keluaran dari tiap-tiap blok, dengan a(t) adalah tapis pelewat rendah yang disebut data filter dan $\mathrm{f}(\mathrm{t})$ adalah tapis pelewat rendah yang disebut loop filter. Jika Sinyal masukan ke Costas Loop dinyatakan dengan persamaan :

$$
u_{i}(t)=m(t) \cdot A_{i} \sin \left(\omega_{i} t+\theta_{i}\right)
$$

dengan $m(t)$ adalah data biner yang dinyatakan dengan persamaan :

$$
m(t)= \begin{cases}+1 & \text {, saat logika } 1 \\ -1 & \text {, saat logika } 0\end{cases}
$$

dan keluaran dari VCO dinyatakan dengan persamaan :

$$
u_{o 1}=A_{o} \sin \left(\omega_{i} t+\theta_{0}\right)
$$

kemudian keluaran dari VCO yang digeser 90 derajat dinyatakan dengan persamaan 


$$
u_{o 2}=A_{o} \cos \left(\omega_{i} t+\theta_{0}\right)
$$

Maka keluaran untai pengali dari jalur Infasa (I) dan Quadrature (Q) dapat dihitung dengan.

1. Di jalur Infasa $(I), u_{d 1}=K_{m I} u_{i}(t) u_{o 1}(t)$, dengan $K_{m I}$ adalah bati dari pengali di jalur Infasa, sehingga

$$
u_{d 1}(t)=K_{m L} \frac{A_{i} A_{o}}{2} m(t) \cos \left(\theta_{i}-\theta_{o}\right)-K_{m l} \frac{A_{i} A_{0}}{2} m(t) \cos \left(2 \omega_{i} t+\theta_{i}+\theta_{o}\right) \text {. }
$$

Setelah dilewatkan pada suatu tapis pelewat rendah akan dihasilkan keluaran :

$$
u_{I}(t)=K_{m I} \frac{A_{i} A_{0}}{2} m(t) \cos \left(\theta_{i}-\theta_{0}\right)
$$

2. Di jalur Quadrature $(Q), u_{d 2}=K_{m Q} u_{i}(t) u_{o 2}(t)$ dengan $K_{m Q}$ adalah bati dari pengali di jalur $Q$, sehingga

$$
u_{d 2}(t)=K_{m Q} \frac{A_{i} A_{0}}{2} m(t) \sin \left(\theta_{i}-\theta_{o}\right)+K_{m Q} \frac{A_{i} A_{0}}{2} m(t) \sin \left(2 \omega_{i} t+\theta_{i}+\theta_{o}\right) \text {. }
$$

Setelah dilewatkan pada suatu tapis pelewat rendah akan dihasilkan keluaran:

$$
u_{Q}(t)=K_{m Q} \frac{A_{i} A_{0}}{2} m(t) \sin \left(\theta_{i}-\theta_{o}\right)
$$

Persamaan keluaran pada pengali ketiga dapat dicari dengan : $u_{d}(t)=u_{I}(t) u_{Q}(t)$, jika bati pengali di jalur I dan Q dibuat sama $K_{m I}=K_{m Q}=K_{m}$, sehingga didapatkan :

$$
u_{d}(t)=K_{m 3} u_{I}(t) u_{Q}(t)=K_{m 3} \frac{\left[K_{m} A_{i} A_{0} m(t)\right]^{2}}{8} \sin \left[2\left(\theta_{i}-\theta_{o}\right)\right]
$$

Karena $m^{2}(t)=1$, maka:

$$
u_{d}(t)=K_{m 3} \frac{\left[K_{m} A_{i} A_{0}\right]^{2}}{8} \sin \left[2\left(\theta_{i}-\theta_{o}\right)\right]
$$

Untuk kondisi sudut kecil $\theta_{0} \approx \theta_{i}$, maka akan digunakan pendekatan $\sin \left[2\left(\theta_{i}-\theta_{0}\right)\right] \approx 2\left(\theta_{i}-\theta_{0}\right)$, sehingga keluaran dari pengali ketiga dapat dinyatakan dengan :

$$
\begin{aligned}
& u_{d}(t)=K_{m 3} \frac{\left[K_{m} A_{i} A_{o}\right]^{2}}{8}\left[2\left(\theta_{i}-\theta_{o}\right)\right] \\
& u_{d}(t)=\frac{K_{d}}{2}\left[2\left(\theta_{i}-\theta_{o}\right)\right]=K_{d}\left(\theta_{i}-\theta_{o}\right)
\end{aligned}
$$

dengan $K_{d}=K_{m 3} \frac{\left(K_{m} A_{i} A_{0}\right)^{2}}{4}$

Keluaran dari pengali ketiga ud(t) akan menjadi masukan ke Loop Filter yang akan menghasilkan keluaran $\left.\mathrm{uf}_{\mathrm{f}} \mathrm{t}\right)$. Keluaran dari Loop Filter ini yang nantinya akan menjadi tegangan pengontrol untuk VCO. Fungsi pindah dari Loop Filter dinyatakan dengan F(s), sedangkan fungsi pindah dari VCO dinyatakan dengan persamaan $\frac{K_{0}}{s}$, dengan $K_{\mathrm{o}}$ adalah tetapan dari VCO. Sehingga Costas Loop dapat dinyatakan dalam sebuah model linier seperti pada Gambar 15 di bawah ini. Model linier Costas Loop ini serupa dengan model linier PLL (Phase Locked Loop). 


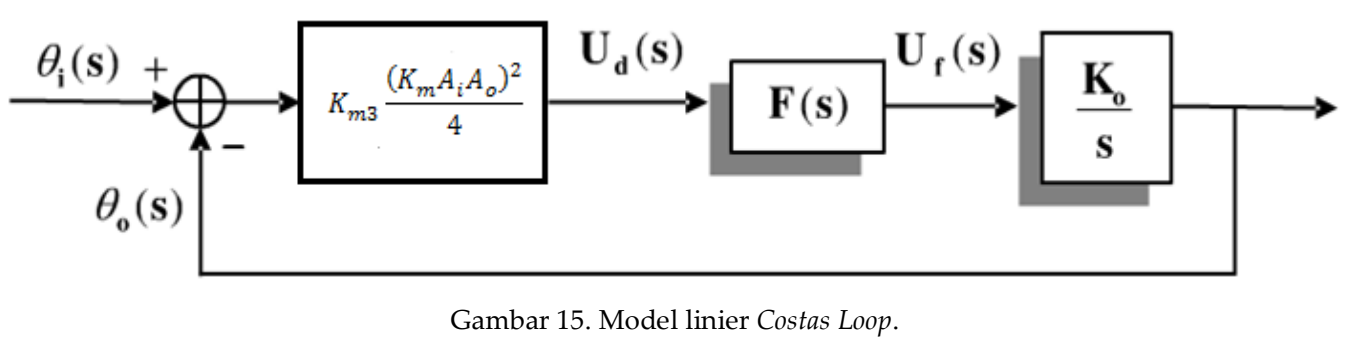

\section{Kesimpulan}

Costas Loop adalah variasi dari PLL agar dapat melakukan demodulasi sinyal-sinyal yang termodulasi secara supressed-carrier, dimana modulasi BPSK termasuk jenis modulasi supressed-carrier, contoh lainnya adalah modulasi AM-DSBSC.

Jika fasa $\Theta_{o}$ pada keluaran (Infasa) ui $(\mathrm{t})$ sama dengan fasa $\Theta_{i}$ pada masukan dari sistem Costas maka keluarannya akan sama dengan isyarat asli $\mathrm{m}(\mathrm{t})$ yaitu " 1 " atau " 0 ".

Kepekaan Costas Loop adalah dua kali dari kepekaan PLL yang ditunjukkan dari keluaran pengali Costas Loop $\mathrm{ud}_{\mathrm{d}}(\mathrm{t})=\sin 2\left(\Theta_{\mathrm{i}}-\Theta_{\mathrm{o}}\right)$ dan keluaran pengali PLL $\mathrm{ud}_{\mathrm{d}}(\mathrm{t})=\sin$ $\left(\Theta_{i}-\Theta_{\circ}\right)$.

\section{Daftar Pustaka}

[1] Couch, Leon W., "Digital and Analog Communication System", 7rd ed, Pearson Education, Inc., New Delhi, 2007.

[2] Lathi, B. P., "Modern Digital and Analog Communication System", Oxford University Press, Inc., New York, 1998.

[3] Feliciano, David P. dan Rivera, Jose L.C., "Digital Implementation of a Second Order Costas Loop Demodulator", Project Report Electrical Engineering University of Puerto Rico, Mei 2004.

[4] Wovaler, Dan H., "Phase-Locked Loop Circuit Design", Prantice-Hall, Inc., New Jersey, 1991.

[5] Chumchairat, Prapat dan Prapakorn Suwanna, "A Costas Loop Circuit Design by Using Exclusive OR Gates Instead of Other Input Mixers Circuits", Departement of Electronics, Engineering Faculty King Mongkut's Institute of Technology Ladkrabang Chalongkrung Rd., Ladkrabang, Bangkok. 